\title{
Early Literary Societies and Their Libraries in Colby College, I 824-78
}

\author{
Mr. Rush is librarian and Miss Herrick is \\ head cataloger at Colby College.
}

$\mathrm{O}^{2}$ N JUNE I9, I820, the first legislature of the new state of Maine passed an act empowering the trustees of the Maine Literary and Theological Institution ${ }^{1}$ to confer such degrees as are usually conferred by universities established for the education of youth. As was true with most institutions of higher education during this period, great stress was laid upon religion. The first extracurricular organization formed by the students was the Philalethian Society, the object of which was to "secure religious information, discuss practical topics in Christian living, and afford mutual sympathy and restraint." Nearly all the students were connected with this religious society, but apparently it did not long provide enough outlet for the energies of the students of the young college, for in a short time they gathered to organize a literary fraternity.

The students justified this organization upon the grounds that its purpose was to be "the improvement of the mind in the arts and sciences, which requires zealous and active exertion." They asserted further :

Men eminent for their attainment in knowledge have risen to distinction by industry and application. The man who seeks for reputation or celebrity in his pursuits, or looks with a longing eye to a conspicuous place on the

${ }^{1}$ The name of Colby College from its founding to Feb. 5, 1821. hill of science, or desires even moderate attainment, must imitate the labors of those who have studied with success. Desirous of improving every opportunity and of embracing every expedient method to enlighten our minds with useful knowledge, convinced of the high importance and sensible of the benefits which result from combined influence and efforts, we hereby agree to associate ourselves together for improvement in literary and scientific attainment.

At the second meeting of the Literary Fraternity on the tenth of March 1824 a code of by-laws was drawn up, of which article eleven reads:

On the Tuesday evening immediately preceding the annual exhibition of the junior class of the college, the society shall hold a special meeting in the College Chapel, which the faculty, the students of the college, the gentlemen and ladies of the village shall be invited to attend. The exercises of the meeting shall be the following, viz.: an oration and a written deputation. The subject of the declamations shall be assigned by the society at their first meeting of the spring term.

The subject chosen for the first oration was "The Necessity of Diligently Studying the Great Principles of Science." The subject of the deputation was "Will It Be Expedient for the United States to Interfere with the Concerns of South America Should She Be Invaded by the Holy Alliance?"

The constitution provided for the office of librarian, with duties as custodian of the books and administrator of the reading room clearly defined. He was later to receive a 
yearly salary of ten dollars for his services. Provision was also made in the by-laws for the treatment of overdue books. Members were charged five and one-half cents weekly for each duodecimo or smaller volume kept after three weeks but were charged twelve and one-half cents for larger volumes.

\section{Activities of Fraternity}

The Literary Fraternity immediately became known for its debates and its library. The weekly meetings were conducted with much vigor, and a valuable collection of books was accumulated from the fees and assessments of its members. The organization held public meetings, brought famous men to the campus, and managed commencement programs and the college paper. For many of the young men who came to college from remote farms and tiny villages, the society opened a vista of the outside world that was indeed an inspiration and a challenge. However, in 1835 a group of students became dissatisfied with its methods and formed a new society known as the Erosophian Adelphi Society. The founding fathers of this branch leaned a little more toward the social side. This, no doubt, was part of the general trend which resulted in the organization of the type of fraternity we have in our colleges today.

It was a privilege to be a member of the Literary Fraternity, as may be inferred from the strictness of its laws and the fact that they were enforced with regularity. All members were expected to take part in the meetings, incurring a fine if they failed to do their share. Absence and tardiness at meetings were frowned upon. In I830 a member was fined six cents for being late. Twelve and one-half cents was the sum exacted for an unexcused absence. One member, conducting himself in a disorderly manner during a meeting in 1834 , was fined twenty-five cents. In 1832 six and onefourth cents was the penalty for nonappear- ance at the debates. For many years the majority of the members took their responsibilities with a deep seriousness. It must be admitted, though, that some of the members slipped occasionally in their duties. At one of the meetings the treasurer and the librarian both failed to appear to present their reports, and it was voted to fine them twenty-five cents each.

Rebukes to members were sometimes gentle but pointed, as in 1862 , when it was voted "to invite Mr. Sawtelle . . . to attend to his duty of opening the reading room." A committee which served to take care of one of the reading rooms, usually faithful, slipped once. The secretary records in April I 857 that it was "voted that the two remaining members look up the third and report at the next meeting if he exists." Evidently he was in secure hiding, for a new member was appointed.

\section{Topics of Debates}

It is of interest to note that the society members debated live topics. In 1832 the subject for discussion at one meeting was "Is It Probable That the United States Will Retain Their Present Form of Government for a Half Century?" The vote was ten in the affirmative and five in the negative. (It would be interesting to speculate what these five believed. Were they early Socialists or possible diehard Tories?) One night the question before the house was "Ought the Government of the United States to Compel South Carolina To Submit to Its Laws, Provided All Other Means Prove Ineffectual?" It was decided in the affirmative, twelve to seven. The next week the question decided in the affirmative was "Ought Congress To Interfere in the Abolition of Slavery?"

Not all of the topics presented at the literary societies were of a political nature, however. As early as 1834 the problem of extracurricular activities at Colby had 
arisen. "Is It Advisable for Students in College to Enlarge the Circle of Their Acquaintances?" was proposed and decided negatively fourteen to ten. "Is the Reading of Fiction Works Beneficial?" called forth a spirited discussion. A margin of one vote in the negative upheld the nonfiction element. "Ambition as a Principle Which Ought To Be Cultivated in the Human Heart" was denied by the overwhelming majority of twenty-two to four. That education should be by textbook alone was a theory upheld when the members met to discuss "Ought a Student To Devote Much Time to Reading During His College Course?"'

Mingled with the truly worth-while subjects of discussion are many which are lighter and more amusing. Interest in the opposite sex is apparent from the following topics-“"Resolved That Persons Courting Should Not Sit Up with Their Sweethearts after Eleven O'Clock in the Evening," and "Are Mankind Bound To Engage in Matrimony?" It is surprising that six hardy souls voted in the negative on this latter question, but they were in the minority. Two years before, in $\mathrm{I} 84 \mathrm{I}$, the members debated "Ought There To Be a Change in the Occupations of the Female Sex?" Again conservatism won, eleven to five. In 1860 a no decision verdict was given on whether "Old Bachelors Who Are Such from Choice (Ought To) Support Old Maids Who Are Such from Necessity." They did not wholly overlook the sterner aspects of life, however. A lengthy debate that aroused fierce opposition was whether "The Study of Heathen Mythology Is More Pernicious than the Reading of Novels." The novel-reading element lost by one vote.

As implied, however, the society meetings were of a decidedly serious nature. One of the outstanding acts of the society was to bring Ralph Waldo Emerson to the campus. He made two visits to the college, the first in 1841 and later in 1863 . His first visit was the occasion of the famous oration, "The Method of Nature." On his second visit in August I863 the country was in the midst of the Civil War and the college group was greatly depleted. To the small number remaining, Emerson spoke on "The Man of Letters." The closing passage made a deep depression upon his listeners, many of whom would be shortly in the service of their country. It ran:

I learn with joy and deep respect, that this college has sent its full quota to the field. I learn, with honoring pain, that you have had your sufferers in the battle.... The times are dark but heroic.... Who would not, if it could be made certain that the new morning of universal liberty should rise on our race by the perishing of one generation, who would not consent to die?

\section{Rivalry between Societies}

Throughout the existence of both the Literary Fraternity and the Erosophian Adelphi Society their programs were almost identical, and naturally enough there was a great amount of rivalry between the two societies. The records show that in I 840 a resolution was offered by the newlyformed Erosophian Adelphi Society "that a Mr. Horatius Wheeler be considered a member of the Erosophian Adelphi and further resolved that the Literary Fraternity have transcended the bounds of courtesy in claiming him as a member of their society. Voted: That a copy of this resolve be handed to Mr. Wheeler and also to the president of the Literary Fraternity." As time went on, however, cordial relationships between the societies became the rule rather than the exception, and we soon find them occasionally holding joint meetings.

The rivalry between the two societies in regard to their respective libraries was clearly shown in many respects. The older society had a greater number of volumes, as 
might be expected. Feeling that this matter should be remedied, in 1843 the librarian of the Adelphi urged all members to contribute any books they might have to the society's collection. His rather caustic reference to the worth of the rival society's volume is worth recording. "Although our library is more valuable than that of the Literary Fraternity, fifteen hundred sounds much better than one thousand, notwithstanding the fact that the extra five hundred may be made up of antique spelling books."

Because of the importance and use of the libraries, the records of both societies abound in reference to them. As early as the third meeting of the Literary Fraternity, it was voted that the standing committee be instructed to make inquiries relative to some literary publications and to report at the next meeting. This privilege of selecting the volumes wanted and needed at the very start was an excellent beginning. Many such libraries too often had their origin with discarded volumes from personal libraries. However, gifts were not unappreciated, for in the minutes of the fourth meeting, Apr. 2, 1824, it was voted to extend a note of thanks to the president of the college, a teacher, and a tutor for their donations to the library.

\section{Support of the Library}

The importance of a good library was deeply felt by the majority of the members, as shown by the minutes of the secretary for Oct. 13, 1824, when it was voted to raise, by a tax on the members, the sum of three hundred dollars (to be paid in instalments over a period of three years), for the purpose of increasing the library. This three hundred dollars was to be spent with the bookseller allowing the best discount. Mr. Hastings, a local bookseller, was first consulted. He agreed to furnish the books at 35 per cent discount. The committee chosen to visit the booksellers in Hallowell reported that "Mr. Lane of that city would furnish books to the amount the society wanted at forty per cent discount, and receive his payment by three instalments as the society proposed." The books were purchased from Mr. Lane. The Literary Fraternity not only showed shrewdness in saving money but in raising money as well. On Oct. 23, 1824, the society heard the following report of the committee who called on the faculty for donations, viz.: That each of the professors subscribed five dollars to be paid in books or cash, and the president ten dollars for which he gave, an order on Mr. Wm. Hastings. The next action regarding an amount to be raised is recorded in the minutes for Mar. 2I, I835: "Resolved, That the members of the society raise by subscription the sum of four hundred dollars for the benefit of the library."

The library funds over a period of years grew slowly, augmented by the subscriptions received. Faculty members were a constant help and support, each year giving generously to the library. In 1853 an ambitious program was inaugurated to raise funds to increase the book collection. Agents were appointed to solicit funds "from gentlemen of the river towns as far as Wiscasset." Purchases resulting from these solicitations included Gibbon's Decline and Fall of the Roman Empire, The Conquest of Peru by Prescott, Headley's Washington and His Generals, and the works of Cicero. The librarians of the society felt some guidance necessary in the choice of books, as may be seen from this excerpt from the report of $185 \mathrm{I}$ :

We suggest in making additions to our library we confine ourselves as much as possible to standard works and when we do purchase popular works such as Ik Marvel's Works, we content ourselves with one or two from each author-enough to enable us to form 
some ideas of the author's style-and the general merits and demerits of his writings. When we have read one or two volumes of such writings we generally know the whole, and when the gilt is worn off from the backs of such we have lost the most valuable part (for a public library, at least). That is to say, their greatest merit in a public library is show.

Nine years later, however, the librarian mentions the need for increasing the department of modern poetry and "lighter sorts of reading."

The members themselves were sometimes slow to offer additions to the collection and needed a bit of jolting, which the librarian proceeded to administer in a report such as that of 1857 . . He remarked, "We can but hope and pray that Providence will increase the number of our benefactors . . . and thus replenish our Library, if we are disposed to do nothing for ourselves." Only a few years earlier, however, a complacent librarian reported to the society that the general appearance of the collection was excellent with every shelf "filled to crowding." Sometime later another librarian presented a dreary picture in his report to the members: "The library is piled up where it was at the beginning of the term and is nothing more and but little less than it has been for some time. In some parts of it the sharp-toothed worm is busy at work at his innocent pastime, gnawing away the musty calves' skins to discover the lore within. We have tried hard to check their ravages by taking down and overhauling the books, but this only enrages them and stimulates them to their depredations with renewed energy."

\section{Fees Used for Library}

In 1859 the initiation fees of the society began to be devoted to the use of the library, an innovation welcomed by the librarian. A catalog of the library was compiled in 1852 and showed eighteen hun- dred volumes arranged by the following classes: biography; journals, voyages, and travels; history; belles lettres; poetry ; periodicals; general science; theology ; classics; and miscellaneous.

Early in the beginning of the administration of the Adelphi Library, there arose the need for some new equipment. It purchased a bookcase and, after prolonged discussion, a lamp. This latter gesture was evidently felt to be a munificent one, worthy of special regard by the members, for a lamplighter was appointed to share with the librarian the duties of attending the reading room. Then the purchase of equipment seemed to stop, and the librarian, like many early librarians, suffered from inattention and neglect. He needed some steps to use in the library room and after awhile purchased them of his own accord. The society, belatedly aware of this need, discussed the advisibility of reimbursing the young man for his outlay. It was finally voted to do so after rather grim discussion, but at a later meeting this vote was revoked; whereupon at the next meeting the librarian announced that he had paid for the steps and they were his property. There is a laconic note in the records of the next week - "Any further mention of the library steps in any manner will be subject to censure." Some of the reports of the early library activities leave no doubt that the position of librarian was taken very seriously. This expression of the finer sensibilities of one of the young librarians of 1850 is an unusual document:

Unexpectedly having been called, in the unsearchable events of the present term, to assume my present responsibilities, being a modest person, I entered upon the more active duties of my office with some trepidation.... Thus left at so early an age of college experience, in the present circumstances I needed, and trust I have received, the hearty sympathies and charitable forebearance of all the Adelphi. 
The students during the early days of Colby were fortunate that there existed two literary societies which developed such good libraries. For many years the patronage of the society libraries far exceeded the use of the college library. The criticism was that the college library was "not well chosen, being made up of such books as our friends could best spare," while according to one early writer, "The libraries of both societies are extensive and of the choicest selections, to which valuable additions are constantly being made by their generous supporters."

With the advent of the Greek letter societies, interest in the purely literary societies gradually declined until they ceased to maintain debates and became merely lending libraries.

Early in 1878 the Literary Fraternity met to consider the following resolution:

Whereas, the meetings of the Literary Fraternity have not been well sustained for a number of years and a large number of its members manifest but little interest in its welfare, the following is resolved: First, that the property of the Literary Fraternity, including the library, be given over into the hands of the faculty. Second, that the Literary Fraternity is hereby adjourned sine die.

In order to give ample time for a thorough discussion of the matter, this meeting was adjourned for three days. But the expediency of virtual dissolution was so evident to all that when the resolutions came to a vote they were passed without any opposition. This step, no doubt, seemed a rash one to the alumni of the fraternity. However, a study of the practical workings of the society during the immediate preceding years shows that this action of the members was merely a formal declaration of the inevitable result.

The Erosophian Adelphi Society gave up its existence the same year. From the two societies the Colby College Library received about four thousand volumes.

The libraries of the early literary societies throughout the country are known to have played a very important part in the development of our present college and university libraries. The transfer of wellselected society collections was a stroke of fortune to the college library which often consisted for the most part of aggregate gifts of charity. We can realize the gain for the institutions that had these society libraries as their foundation collections. What was lost thereby we can less easily measure, that is, the individual student interest and active participation in the selection of books and management of the libraries.
A Recent study, "Monographic Holdings of American Libraries in the Medieval and Renaissance Fields" by S. H. Thomson, which appeared in Progress of Mediaeval Studies and Renaissance in the United States of America and Canada, Bulletin No. I8, June 1944, should not escape the attention of the librarian of any scholarly library. Dr. Thomson's brief discussion of American institutional bookbuying is pertinent and pointed. He finds that "a vast amount of pure and unmitigated trash in the fields of medieval and renaissance studies is purchased by institutional libraries in America and that a great deal of the best and most enduring is not acquired." The improvement of this situation is the joint concern of librarians and scholars.-Eugene H.Wilson, University of Colorado Libraries, Boulder. 